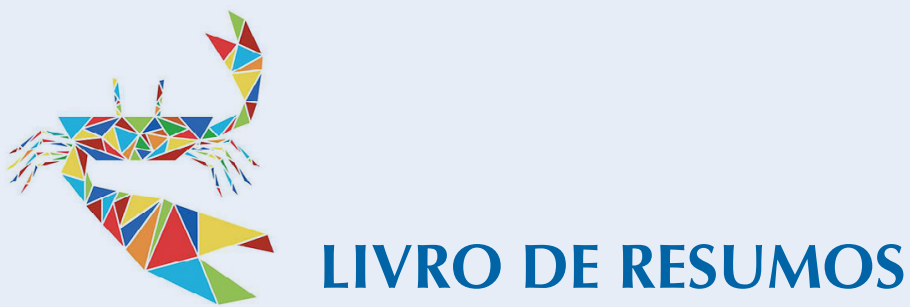

\title{
MORFOLOGIA DA MANDÍBULA DE AEGLA LEACH, 1820 (ANOMURA, AEGLIDAE)
}

\author{
Santos, S. ${ }^{1, *}$; Dalla Lana, A.L. ${ }^{1}$ \& Bartholomei-Santos, M.L. ${ }^{1}$ \\ ${ }^{1}$ Universidade Federal de Santa Maria (UFSM), Departamento de Ecologia e Evolução, Laboratório de Carcinologia. \\ *Autor correspondente: sandro.santos@ufsm.br
}

\begin{abstract}
Atualmente existem 85 espécies e subespécies descritas para o gênero Aegla Leach, 1820. Porém, este número está subestimado. Além destas, há um conjunto de espécies crípticas, recém descobertas, aguardando para serem descritas. No entanto, em função do aspecto conservativo das espécies desse gênero, há uma grande dificuldade de diferenciá-las morfologicamente. Aegla longirostri é um exemplo de um complexo de espécies morfologicamente semelhantes, porém, molecularmente distintas. Logo, este estudo busca avaliar a utilização de novas estruturas diagnósticas para a diferenciação morfológica entre as espécies desse complexo. Iniciamos pelo aparelho bucal, com ênfase nas mandíbulas (direita, esquerda), explorando previamente a população do Rio Vacacai-Mirim. Esta peça localiza-se no terceiro segmento cefálico, articula-se com o epístomo e possui a borda de corte com dois sulcos que se encaixam e quatro dentes. O material foi dissecado e analisado com o auxílio de estereomicroscópio e microscópio óptico. Os detalhes foram desenhados e fotografados. Foram encontrados seis tipos diferentes de cerdas, além das simples: 1) Metade basal espessa e metade distal delgada, com pelos em toda a extensão; 2) Metade basal espessa, afilando gradativamente em direção distal, sem pelos; 3) Curta, com metade do tamanho da cerda simples, com poro distal; 4) Curta, com metade do tamanho da cerda simples, sem poro distal; 5) Curta, com metade do tamanho da cerda simples, sem poro distal, com pelos em toda a extensão; 6) Mesmo tamanho da cerda simples, com a região mediana espessa. Na porção mediana ventral, próximo à margem interna, há um tufo com dois tipos de cerdas, as simples e as do tipo 1. O palpo está inserido na margem externa da mandíbula, porção mediana, e estende-se para frente, contornando sua borda distal. Esta peça é dividida em dois segmentos, o proximal com formato cilíndrico e o distal oval achatado. No segmento distal há cerdas simples, dos tipos 2 e 3, distribuídas aleatoriamente. Na sequência, estas características serão comparadas entre as diferentes populações do complexo Aegla longirostri.
\end{abstract}

Palavras-chave: caracteres taxonômicos, espécies crípticas, taxonomia. 